\title{
Impact of Service Orientation on Frontline Employee Service Performance and Consumer Response
}

\author{
Rong-Da Liang \\ Department of Marketing and Logistics Management, National Penghu University \\ No.300, Liuhe Rd., Magong City, Penghu County 88046, Taiwan, R.O.C \\ Tel: 886-6-926-4115 Ext: 5522 E-mail: rdliang@npu.edu.tw
}

\author{
Hsing-Chau Tseng \\ Graduate School of Business and Operations Management, Chang Jung Christian University \\ 396, Chang Jung Rd., Sec.1, Kway Jen, Tainan 71101, Taiwan, R.O.C \\ Tel: 886-6-278-5123 Ext: 2020 E-mail: hsingchau@mail.cjcu.edu.tw
}

Yun-Chen Lee (Corresponding author)

Graduate School of Business and Operations Management, Chang Jung Christian University

No. 396, Chang Jung Rd., Sec.1, Kway Jen, Tainan 71101, Taiwan, R.O.C

Tel: 886-937-366-869 E-mail: yunchen222@gmail.com

\begin{abstract}
As product and price become less important, managers search for new ways to differentiate themselves in a buyer-seller relationship. Increasingly, businesses have to focus on service orientation to differentiate themselves from their competitors. As consumer loyalty depends primarily upon rendering quality service, the delivery process among business service orientation, frontline service employee performance and consumer response deserves more attention. This article explores some of the ways in which service orientation can be used as an appropriate alternative to the more traditional business methods. This study analyzes the dyadic data collected from 247 questionnaires distributed to consumers and employees across 17 branches of a financial service company. The results show that service orientation positively affects employee service performance but negatively affects consumer loyalty. Employee service performance positively influences consumer loyalty and indirectly positively influences word-of-mouth of consumers.
\end{abstract}

Keywords: Service orientation, Service performance, Consumer loyalty, Word-of-mouth

\section{Introduction}

Recent marketing literature has acknowledged the role of a company's service orientation in achieving a sustainable competitive advantage. This service orientation, the relationship and strategy between the company and the customer, is arguably the most important area for a business to study. Over the last decade, it has become crucial for businesses to fundamentally understand and satisfy consumer needs in order to succeed in a highly competitive market environment (Keillor, Parker and Pettijohn, 1999). These new considerations, while extended in scope, clarify several points about service orientation. As a result, its antecedents and consequences have been widely studied (Homburg, Hoyer, and Fassnacht, 2002; Kelley, 1992; Lytle and Timmerman, 2006; Marinova, Ye and Singh, 2008).

The impact of service orientation may be viewed as a roadblock that businesses must navigate in order to reduce negative effects generated from interaction with consumers. A vast majority of the attention paid to the consequences of service orientation has concentrated on its relationship with business performance (Homburg et al., 2002; Lytle, et al., 1998; Lytle, Lynn, and Bobek, 2000; Di Mascio, 2010). However, relatively little academic research has focused on the role of service orientation in influencing employees and customer response. Moreover, the research is scant in addressing other possible consequences, such as the effect of service orientation on the operational level of employees (Wu, Liang, Tung, and Cheng, 2008). These impacts of service orientation can be applied only after the basis limitation impacts have been applied but before the operational level of employees are tested. Thus, this study simultaneously examines the various consequences of service orientation. 
Recent developments have given heightened importance to employees as important channels to deliver service to customers that will reduce the negative impact. The Albrecht (1988) "service triangle" indicates the tripartite relationship among the service organization, the service provider, and the customers. In the meantime, service organizations have begun to consider the roles their employees should play in achieving a sustainable competitive advantage (Asif and Sargeant, 2000). If employees are part of a solid service culture and receive management support for delivering improved customer service, this has a positive impact and influences the structuring of how an organization pursues service orientation. One which favors excellent service quality can lead to employee behavior and attitudes which, in turn, creates higher value and a better result. In addition, the experience will lead to increased consumer loyalty and positive word-of-mouth.

Assumptions that have been made for the purpose of our analysis include how a company's service orientation affects employees' service performance and eventually customer loyalty and word-of-mouth. This current research begins with the development of the hypotheses to be tested in the study with an objective dyadic sample applied. The methodology used in the study is then described, after which the empirical results are presented. The article concludes with a discussion of research and managerial implications.

\section{Literature Review}

\subsection{Attraction-Selection-Attrition Model}

The Attraction-Selection-Attrition (ASA) Model (Schneider and Goldstein, 1995; Schneider and Bowen, 1995) provides the theoretical background for the general framework of our study. According to this theory, individuals have diverse attitudes in the same environment (e.g., organization). However, over time, people within an organization become more similar in their dispositions and, consequently, more homogenous in their attitudes (Schneider et al., 1995). This result arises because the individuals in an organization are affected by the same situational influences, and thus their attitudes should converge (Ryan, Schmit, and Johnson, 1996). According to Schneider et al. (1995), a positive and satisfactory organizational climate allows employees to serve consumers with excellent service and is responsive to organizational and consumer goals. Therefore, once an organization pursues premium service orientation, consumer loyalty should be related to employees' service performance and to the homogeneity of the working environment.

\subsection{Relationships among service orientation, employee service performance and consumer loyalty}

According to Hogan, Hogan, and Busch (1984), service orientation can be defined as "a set of attitudes and behaviors affecting the quality of interaction between an organization's employees and its customers." In other words, it is the disposition used when providing service to the consumers. Liao and Chuang (2004) found empirical support for a positive relationship between service orientation (e.g., service environment) and frontline employee service performance. Furthermore, Alge, Gresham, Heneman, Fox, and McMaster (2002) indicated that customer service oriented employees are a key factor of customer service. Service organizations that emphasize service culture or service orientation can enhance employees' service behavior.

In focusing on the service triangle, the idealistic state exists when there are positive relationships between the service organization-service provider, service organization-consumer, and service provider-consumer. It represents a balanced triad and the optimal state in which the consumer has no need cognitively to distort, reevaluate, or behaviorally withdraw from the situation. When an organization maintains positive relationships with both the provider and the consumer, several desirable outcomes are likely (Kotler, 2000). Employees will experience increased levels of motivation, satisfaction, and commitment and decreased levels of intent to withdraw from the organization (De Man, Gemmel, Vlerick, Rijk, and Dierckx, 2002). There will be a reduction in the gap between consumer expectations and actual service quality, and consumers will be more loyal and will have higher repurchase intentions, as compared to when positive relations do not exist among all three parties (Castro, Armario, and Del Río, 2005). As a result, market orientation theory (Castro et al., 2005, Day 1994; Jaworski and Kohli 1993; Slater and Narver 1994; Wright, Pearce, and Busbin, 1997) indicates that firms with superior service strategy or facilitation should have superior customer knowledge, excellent service performance and should be able to develop offerings that better satisfy the needs and wants of target customers.

Marketing literature indicates that an employees' service performance (e.g., good interpersonal skills; employees' credibility) positively impacts customer satisfaction and loyalty (Alge et al., 2002; Hansen, Sandvik, and Selnes, 2003). Bowen and Schneider (1988) noted three defining characteristics of service: intangibility, simultaneous production and consumption, and customer co-production. Customer experience thus is an important factor. Extant research (e.g., Castro et al., 2005; Hwang and Chi, 2005) suggests there are certain components of the service delivery process for which the consumer holds the provider responsible. Specifically, the consumer expects the provider to be reliable, responsive, competent, courteous, credible, and understanding. 
Consumers further expect providers to exhibit appropriate demeanor, communicate effectively, and inspire confidence. Finally, the quality of the interaction between employee and consumer is critical in determining customer satisfaction and loyalty (Liao et al., 2004; Lytle et al., 2006).

According to these arguments, the following hypotheses are proposed:

H1. Service orientation has a positive effect on employee service performance

H2. Service orientation has a positive effect on consumer loyalty

H3. Employee service performance has a positive effect on consumer loyalty

\subsection{Relationships between consumer loyalty and word of mouth}

According to Zeithaml, Berry, and Parasuraman (1996), loyal customers forge bonds with the company and behave differently from disloyal customers. In this assumption, we can expect customer loyalty to impact behavioral outcomes and, finally, the profitability of a company. Srinivasan, Anderson, and Ponnavolu (2002) indicated that customers with higher loyalty can enhance the opportunity to provide positive word-of-mouth or willingness to pay more. Dick, Basu (1994), Hagel, and Amstrong (1997) noted that loyal customers are more likely to promote a company with a positive perspective. Thus we may subsequently recognize that the loyalty of customers will positively relate to their word-of-mouth behavior.

H4. Consumer loyalty is positively related to word of mouth

\section{Research method}

In line with the literature review and the purpose of study, the conceptual framework of the study was configured as illustrated in Figure 1.

\subsection{Measure}

In order to test the proposed hypotheses, an empirical study that is quantitative in nature was conducted. The analysis was based on dyadic data; that is, involving judgments by frontline employee and their consumers, an approach that rules out the risk of a common method bias.

Most of the scales we used were developed on the basis of a review of the extant literature and interviews with practitioners. This study adopted a 5-point Likert scale for a questionnaire which comprised of questions already developed for other studies but modified to serve this study's purposes.

As a result, the questionnaire was pre-tested and further refined on the basis of comments from marketing managers and scholars during the pretest. The unit of analysis was an individual front service employee in a financial company and the consumer base for which this employee is responsible.

The service orientation and frontline employee service performance was measured with five and seven items based on the work of Liao et al. (2004). Consumer loyalty and word-of-mouth was measured through items adapted from the work of Lichtenstein Lichtenstein, Drumwright, and Braig (2004). A complete list of items appears in Table 1.

\subsection{Sample and data collection}

The financial service industry was selected for the first phase for two reasons: (1) customers desire higher quality service and employee response in a highly competitive environment (George and Bettenhausen, 1990; Keillor et al., 1999), and (2) customer management relationships (CRM) is the basis of overall strategy consideration for most financial service companies (Fitzgibbon and White, 2005).

In the second phase, service oriented businesses were selected that met three criteria. First, financial holding companies with branch systems were chosen because the branch companies are located in different areas with different customer segmentations (such as Northern, Central and Southern Taiwan) with different influences of regional competition and internal administration, which facilitates effective measurement of the research topic. Second, companies with fully developed customer database systems were selected to facilitate investigation of customer-employee relationships. Third, companies whose managers agreed to assist in customer selection and questionnaire distribution were chosen (Hellier, Geursen, Carr and Rickard, 2003). A specific financial company was then chosen as the research subject.

In the third phase, of 35 branches of a specific financial company, 17 branches were contacted with a random sampling method. Questionnaires of dyadic data from employees (such as A1) and consumers (such as B1) were distributed to the 17 branches which were then distributed to service personnel by branch managers. Service personnel were asked to randomly distribute consumer questionnaires to consumers on the same date the 
questionnaire forms arrived. After the completion of the questionnaire forms, branch managers returned the questionnaire forms back to the researchers.

In total, 300 questionnaires were distributed to employees and another 300 were distributed to consumers of which 275 and 254 completed forms were collected, respectively. Additionally, 247 copies were counted as valid (a fully completed A1 and B1 form).

\section{Results}

\subsection{Factor and reliability analysis}

This study analyzed the validity and reliability of all scales using exploratory factor analysis and Cronbach's $\alpha$ coefficient. The dimension $\alpha$ value ranged from $0.67 \sim 0.87$. Although the reliability of service orientation was only .67, the overall reliability for all scales exceeded the acceptable level of 0.7 , as recommended by Nunnally (1978). The relationship between SO2 and SO5 and service orientation was below 0.5. After removing these two questions, reliability values of 0.78 were obtained. Regarding the analytical results of employee service performance, the ESP7 and dimension was less than 0.5. The item was removed and a reliability value of 0.87 was obtained. The resulting Cronbach $\alpha$ values of consumer loyalty and word of mouth were 0.78 , and 0.83 , respectively.

\subsection{Confirmatory factors analysis}

This study used two-stage confirmatory factors analysis to test whether all dimensions had sufficient convergent and discriminated validity. For convergent validity, the results of confirmatory factors analysis for all dimensions are listed in Table 2. All of the adequacy indicators were close to the ideal, and the $t$ values for the factor loading of all measurement items reached the level of significance $(p<0.05)$. These results suggest that the AVE, Reliability, and convergent validity of all dimensions were within the acceptable range.

\subsection{Structure model analysis}

Regarding the assessment of the overall fitness of the patterns in this study, Bagozzi and Yi (1988) believed a structure model can be done using preliminary fit criteria, overall model fit, and internal model fit. Applying these ideas, the analytical results suggest that the basic fitness indicator of this research: (1) may not have a significant negative value, (2) its factor loading may not be too low or too high, and (3) it should reach a level of significance. All of the three standards were met, as shown in Table 3, and were generally acceptable.

Among the overall pattern fitness indicators, where Chi-square/d.f. $=1.96$, GFI $=0.91, \mathrm{RMR}=0.029$, and RMSEA $=0.062$, all indicators were tenable, and only AGFI was almost tenable. Internal structure fitness was assessed using the following criteria: (1) individual reliability exceeding 0.5 , (2) reliability of potential variable combination exceeding 0.7, and (3) AVE of potential variance exceeding 0.5. Although the extracted variance (AVE) of service orientation was below 0.5, Fornell and Larcker (1981) argued that "based on the reliability for the construct $\left(\rho_{\mathrm{y}}\right)$ alone, researchers can conclude that construct convergent validity is adequate despite over $50 \%$ of the variance because of error induced." The analytical results suggest that all indicators are tenable, and thus this pattern should have good internal structural fitness.

The significant findings of this research include that the relationship between service orientation $\left(\gamma_{11}=0.31\right)$ positively influences employee service performance. It was also found that in the pursuit of excellent consumer service, the more intense the service environments, the more likely that a high standard employee service performance will be established. However, service orientation $\left(\gamma_{21}=-0.22\right)$ may negatively influence consumer loyalty, which needs to be further tested and mediated by the different types of hypotheses. Further, employee service performance $\left(\beta_{21}=0.19\right)$ and consumer loyalty indicated that the more an employee stresses a high standard of service, the higher level of consumer loyalty will be obtained. Finally, consumer loyalty $\left(\beta_{32}=0.60\right)$ positively influences word-of-mouth. That is, the likelihood of positive word of mouth increases with improving consumer loyalty.

\section{Conclusion and Discussion}

This study examines hypotheses 1 to 4 using quantitative analysis which is demonstrated to be significant and also appears to yield reasonable results. It is particularly important that our study has demonstrated the presence of this relationship based on dyadic data because this approach rules out the possibility on a common method bias. Although a positive link among business service orientation, employees' service performance and consumer response has frequently been suggested, attraction-selection-attrition model research based on sound empirical analysis exploring this link is scarce. The main contribution of this study has been to identify the associations among an organization's service orientation, excellent employees' service performance and consumer response 
(e. g., Lytle et al. 1998; Alge et al., 2002). The findings presented in this study have important implications for employees from a solid service environment who receive management support to provide better customer service. At the same time, an employees' service performance does have a positive impact on consumer loyalty (e.g., Liao et al., 2004). Further, consumer loyalty having a positive impact on positive word-of-mouth was confirmed.

Service orientation, however, has negative influences on consumer loyalty. According to the balance theory (Carson, Carson, and Roe, 1997), this situation is possible. This theory proposes three factors which shape relationships for parties in the triad: sentiment (liking and disliking), attitude (sharing of similar values and opinions about other persons or entities), and unit relation (conditions under which entities belong together, such as ownership). The idealistic state exists when there are positive relationships between the service organization-service provider, service organization-consumer, and service provider-consumer. The service provider (e.g., frontline employee) and the service organization are not always equated in the minds of the consumer (Carson et al., 1997). Thus, a relationship system is called balanced if the two persons have the same attitude toward an object; in an unbalanced, which is stated the two individual directions in the attitudes toward the object. Therefore, when a consumer becomes loyal to a service provider, the consumer may be willing to tolerate organizational inefficiencies as long as the provider remains employed by the enterprise.

This research has both managerial and research implications in that a dynamic perspective is used to show the evolution of relationships. From a managerial perspective, employees' service performance can establish consumer loyalty based on providing an excellent service environment. The service orientation, however, has a negative influence on consumer loyalty, which means that triad are in an unbalanced situation. Management needs to take appropriate remedial action to change this situation to improve the relationship between service organization and consumers. From a research perspective, our analysis provides a theoretical basis to understand their relationships. Moreover, how service orientation may negatively influence consumer loyalty needs to be further tested and studied through different types of hypotheses.

\subsection{Limitations and Avenues for future research}

Although this study does not use the key-informant advocated by traditional theories as the main measurement method, employees and consumers more accurately reflect the actual working environment in an organization (Lytle et al., 2006; Saura et al., 2005) and can more precisely understand consumer cognition, thus reducing the problem of common method bias. Additionally, cross section data is used to demonstrate verification of the study, and the longitudinal method is not used for information collection. Therefore, care is needed in making inferences regarding causal relationships. Also, this study suffers from limitations of scope in that to simultaneously study the interactive relationship between business employees and consumers. This study focuses only one financial holding company, generalizing the results to other segments of the financial sector may not be possible without making changes to the magnitude and direction of the relationships among constructs. Meanwhile, this work does not discuss the influences on the relationships among possible variables in the financial service industry, such as firm size and type.

Based on this research, several avenues for future research can be suggested. Mediator may be available between service orientation and consumer loyalty, and may change their negative relationships, however we didn't discuss that in this work. Therefore, future studies need to find other variables (such as relationship quality) to create a new construct. In addition, empowerment, for example, is a central dictate of quality management. Organizations experiencing negative relations with consumers might empower providers to take any action necessary to meet customer demands. Research should examine how consumers can be empowered to transform negative linkages into positive ones. Such actions might prevent consumers from withdrawing from the triad.

\section{References}

Albrecht, K. (1988). At America's service: How corporations can revolutionize the way they treat their customers: Business One Irwin.

Alge, B., Gresham, M., Heneman, R., Fox, J., \& McMasters, R. (2002). Measuring customer service orientation using a measure of interpersonal skills: A preliminary test in a public service organization. Journal of Business and Psychology, 16(3), 467-476.

Asif, S., \& Sargeant, A. (2000). Modelling internal communications in the financial services sector. European Journal of Marketing, 34(3/4), 299-317.

Bagozzi, R., \& Yi, Y. (1988). On the evaluation of structural equation models. Journal of the academy of marketing science, 16(1), 74-94.

Bowen, D., \& Schneider, B. (1988). Services marketing and management: Implications for organizational 
behavior. Research in organizational behavior, 10, 43-80.

Bowen, D., Siehl, C., \& Schneider, B. (1989). A framework for analyzing customer service orientations in manufacturing. Academy of Management Review, 14(1), 75-95.

Carson, P., Carson, K., Knouse, S., \& Roe, C. (1997). Balance Theory applied to Service Quality: a focus on the organization, provider, and consumer triad. Journal of Business and Psychology, 12(2), 99-120.

Castro, C., Armario, E., \& Rio, M. (2005). Consequences of market orientation for customers and employees. European Journal of Marketing, 39(5/6), 646-675.

Day, G. (1994). The capabilities of market-driven organizations. the Journal of Marketing, 58(4), 37-52.

De Man, S., Gemmel, P., Vlerick, P., Van Rijk, P., \& Dierckx, R. (2002). Patients' and personnel's perceptions of service quality and patient satisfaction in nuclear medicine. European Journal of Nuclear Medicine and Molecular Imaging, 29(9), 1109-1117.

Di Mascio, R. (2010). The Service Models of Frontline Employees. Journal of Marketing, 74(4), 63-80.

Dick, A., \& Basu, K. (1994). Customer loyalty: toward an integrated conceptual framework. Journal of the academy of marketing science, 22(2), 99-113.

Fitzgibbon, C., \& White, L. (2005). The role of attitudinal loyalty in the development of customer relationship management strategy within service firms. Journal of Financial Services Marketing, 9(3), 214-230.

George, J., \& Bettenhausen, K. (1990). Understanding prosocial behavior, sales performance, and turnover: A group-level analysis in a service context. Journal of Applied Psychology, 75(6), 698-709.

Hagel, J. (1999). Net Gain: Expanding markets through virtual communities. Journal of Interactive Marketing, 13(1), 55-65.

Hagel, J., \& Armstrong, A. (1997). Net Gain-Expanding markets through virtual communities. McKinsey Quarterly, 140-146.

Hansen, H., Sandvik, K., \& Selnes, F. (2003). Direct and indirect effects of commitment to a service employee on the intention to stay. Journal of Service Research, 5(4), 356-368.

Hellier, P., Geursen, G., Carr, R., \& Rickard, J. (2003). Customer repurchase intention: A general structural equation model. European Journal of Marketing, 37, 11(12), 1762-1800.

Hogan, J., Hogan, R., \& Busch, C. (1984). How to measure service orientation. Journal of Applied Psychology, 69(1), 167-173.

Homburg, C., Hoyer, W., \& Fassnacht, M. (2002). Service orientation of a retailer's business strategy: dimensions, antecedents, and performance outcomes. Journal of Marketing, 66(4), 86-101.

Hwang, I., \& Chi, D. (2005). Relationships among internal marketing, employee job satisfaction and international hotel performance: an empirical study. International Journal of Management, 22(2), 285-293.

Jaworski, B., \& Kohli, A. (1996). Market orientation: review, refinement, and roadmap. Journal of Market-Focused Management, 1(2), 119-135.

Keillor, B., Stephen Parker, R., \& Pettijohn, C. (1999). Sales force performance satisfaction and aspects of relational selling: Implications for sales managers. Journal of Marketing Theory and Practice, 7(1), 101-115.

Kelley, S. (1992). Developing customer orientation among service employees. Journal of the academy of marketing science, 20(1), 27-36.

Kotler, P. (2000). Marketing Management. The Millennium Edition. Prentice Hall.

Liao, H., \& Chuang, A. (2004). A multilevel investigation of factors influencing employee service performance and customer outcomes. The Academy of Management Journal, 47(1), 41-58.

Lichtenstein, D., Drumwright, M., \& Braig, B. (2004). The effect of corporate social responsibility on customer donations to corporate-supported nonprofits. Journal of Marketing, 68(4), 16-32.

Lynn, M., Lytle, R., \& Bobek, S. (2000). Service orientation in transitional markets: does it matter? European Journal of Marketing, 34(3/4), 279-298.

Lytle Peter, W., \& Richard, S. (1998). SERV* OR: a managerial measure of organizational service-orientation. Journal of Retailing, 74(4), 455-489.

Lytle, R., \& Timmerman, J. (2006). Service orientation and performance: an organizational perspective. Journal 
of Services Marketing, 20(2), 136-147.

Marinova, D., Ye, J., \& Singh, J. (2008). Do frontline mechanisms matter? Impact of quality and productivity orientations on unit revenue, efficiency, and customer satisfaction. Journal of Marketing, 72(2), 28-45.

Nunnally, J. (1978). Psychometric theory. NY: McGraw-Hill Inc.

Ryan, A., Schmit, M., \& Johnson, R. (1996). Attitudes and effectiveness: Examining relations at an organizational level. Personnel Psychology, 49(4), 853-882.

Saura, I., Contri, G., Taulet, A., \& Velazquez, B. (2005). Relationships among customer orientation, service orientation and job satisfaction in financial services. International Journal of Service Industry Management, 16(5), 497-525.

Schneider, B., \& Bowen, D. (1995). Winning the service game: Harvard Business Press.

Schneider, B., GOLDSTIEIN, H., \& Smith, D. (1995). The ASA framework: An update. Personnel Psychology, 48(4), 747-773.

Slater, S., \& Narver, J. (1994). Does competitive environment moderate the market orientation-performance relationship? The Journal of Marketing, 58(1), 46-55.

Srinivasan, S., Anderson, R., \& Ponnavolu, K. (2002). Customer loyalty in e-commerce: an exploration of its antecedents and consequences. Journal of Retailing, 78(1), 41-50.

Wright, N., Pearce, J., \& Busbin, J. (1997). Linking customer service orientation to competitive performance: does the marketing concept really work? Journal of Marketing Theory and Practice, 5(4), 23-34.

Wua, C., Lianga, R., Tungb, W., \& Changc, C. (2008). Structural relationships among organisation service orientation, employee service performance, and consumer identification. The Service Industries Journal, 28(9), $1247-1263$.

Zeithaml, V., Berry, L., \& Parasuraman, A. (1996). The behavioral consequences of service quality. Journal of Marketing, 60(2), 31-46.

Table 1. Scale definition

\begin{tabular}{|c|c|c|}
\hline Dimension & Items & Source \\
\hline $\begin{array}{l}\text { Service } \\
\text { orientation }\end{array}$ & $\begin{array}{l}\text { A customer should never contact me unless they are firmly committed to } \\
\text { buying.(r) } \\
\text { I treat each buyer as if they are my only customer. } \\
\text { My job is to sell product, not deal with any post-sale problems a buyer } \\
\text { might encounter.(r) } \\
\text { The amount of money involved determines the attention I devote to a } \\
\text { buyer.(r) } \\
\text { The amount of time and number of calls required to obtain a sale are not } \\
\text { important. }\end{array}$ & $\begin{array}{l}\text { Liao et al., } \\
2004\end{array}$ \\
\hline $\begin{array}{l}\text { Employee service } \\
\text { performance }\end{array}$ & $\begin{array}{l}\text { Being friendly and helpful to customer. } \\
\text { Approaching customers quickly. } \\
\text { Asking good questions and listening to find out what a customer wants. } \\
\text { Being able to help customers when needed. } \\
\text { Pointing out and relating item features to a customer need. } \\
\text { Suggesting items customers might like but did not think of. } \\
\text { Explaining an item's Features and benefits to overcome a customer's } \\
\text { objections. }\end{array}$ & $\begin{array}{l}\text { Liao et al., } \\
2004\end{array}$ \\
\hline Consumer loyalty & $\begin{array}{l}\text { Try all types of innovative services. } \\
\text { Use all types of value-added services. } \\
\text { Use innovative service provided during promotion period. } \\
\text { Pay attention to service information. }\end{array}$ & $\begin{array}{l}\text { Lichtenstein } \\
\text { et al., } 2004\end{array}$ \\
\hline Word of mouth & $\begin{array}{l}\text { Use items with imprinted company logo or symbol. } \\
\text { Refer benefits of a company to friends, family members, or colleagues. } \\
\text { counterattack negative news about a company from other people }\end{array}$ & $\begin{array}{l}\text { Lichtenstein } \\
\text { et al., } 2004\end{array}$ \\
\hline
\end{tabular}

r: reverse item 
Table 2. Confirmatory factor analysis (CFA) table of all the dimensions

\begin{tabular}{|c|c|c|c|c|c|}
\hline Dimensions & Items & Standard loading & Error & $\mathrm{CR}$ & AVE \\
\hline \multirow{3}{*}{$\begin{array}{l}\text { Service } \\
\text { Orientation }\end{array}$} & SO1 & 0.76 & 0.42 & \multirow[t]{3}{*}{0.79} & \multirow[t]{3}{*}{0.55} \\
\hline & $\mathrm{SO} 2$ & 0.84 & 0.29 & & \\
\hline & SO3 & 0.61 & 0.62 & & \\
\hline \multirow{6}{*}{$\begin{array}{ll}\text { Employee } & \text { job } \\
\text { satisfaction } & \end{array}$} & ESP1 & 0.86 & 0.26 & \multirow[t]{6}{*}{0.92} & \multirow[t]{6}{*}{0.61} \\
\hline & ESP2 & 0.87 & 0.25 & & \\
\hline & ESP3 & 0.91 & 0.17 & & \\
\hline & ESP4 & 0.90 & 0.2 & & \\
\hline & ESP5 & 0.64 & 0.59 & & \\
\hline & ESP6 & 0.67 & 0.55 & & \\
\hline \multirow[t]{4}{*}{ Consumer loyalty } & CL1 & 0.82 & 0.33 & \multirow[t]{4}{*}{0.89} & \multirow[t]{4}{*}{0.66} \\
\hline & CL2 & 0.84 & 0.29 & & \\
\hline & CL3 & 0.81 & 0.34 & & \\
\hline & CL4 & 0.78 & 0.4 & & \\
\hline \multirow[t]{3}{*}{ Word of mouth } & WM1 & 0.77 & 0.41 & \multirow[t]{3}{*}{0.86} & \multirow[t]{3}{*}{0.67} \\
\hline & WM2 & 0.79 & 0.27 & & \\
\hline & WM3 & 0.84 & 0.29 & & \\
\hline
\end{tabular}

$\chi^{2}=220.01 \quad \chi^{2} / \mathrm{df}=2.245 ; \mathrm{GFI}=0.9 ; \quad \mathrm{AGFI}=0.86 ; \mathrm{NFI}=0.96 ; \mathrm{NNFI}=0.97 ; \quad \mathrm{CFI}=0.98 ; \mathrm{IFI}=0.98 ; \mathrm{RMR}=0.031$; RMSEA $=0.071$

Table 3. Structure model analysis

\begin{tabular}{|c|c|c|c|c|}
\hline Dimensions & Standard loading & Error & $\mathrm{CR}$ & AVE \\
\hline \multicolumn{5}{|c|}{ Service orientation } \\
\hline SO1 & 0.66 & 0.56 & \multirow{3}{*}{0.70} & \multirow{3}{*}{0.45} \\
\hline $\mathrm{SO} 2$ & 0.84 & 0.30 & & \\
\hline $\mathrm{SO} 3$ & 0.47 & 0.78 & & \\
\hline \multicolumn{5}{|c|}{ Employee service performance } \\
\hline ESP1 & 0.8 & 0.37 & \multirow{6}{*}{0.89} & \multirow{6}{*}{0.57} \\
\hline ESP2 & 0.8 & 0.36 & & \\
\hline ESP3 & 0.86 & 0.25 & & \\
\hline ESP4 & 0.82 & 0.33 & & \\
\hline ESP5 & 0.58 & 0.55 & & \\
\hline ESP6 & 0.59 & 0.65 & & \\
\hline \multicolumn{5}{|c|}{ Consumer loyalty } \\
\hline CL1 & 0.78 & 0.61 & \multirow{4}{*}{0.80} & \multirow{4}{*}{0.50} \\
\hline CL2 & 0.82 & 0.67 & & \\
\hline CL3 & 0.64 & 0.41 & & \\
\hline CL4 & 0.55 & 0.30 & & \\
\hline \multicolumn{5}{|c|}{ Word of mouth } \\
\hline WM1 & 0.68 & 0.54 & \multirow{3}{*}{0.79} & \multirow{3}{*}{0.55} \\
\hline WM2 & 0.75 & 0.44 & & \\
\hline WM3 & 0.79 & 0.37 & & \\
\hline
\end{tabular}

$\chi 2=196.09, \quad \chi 2 / \mathrm{df}=1.96 \quad$ (d.f. $=100), \quad \mathrm{GFI}=0.91, \quad \mathrm{AGFI}=0.88, \quad \mathrm{NFI}=0.92, \quad \mathrm{NNFI}=0.95, \quad \mathrm{CFI}=0.96$, $\mathrm{IFI}=0.96, \mathrm{RMR}=0.029, \mathrm{RMSEA}=0.062$.

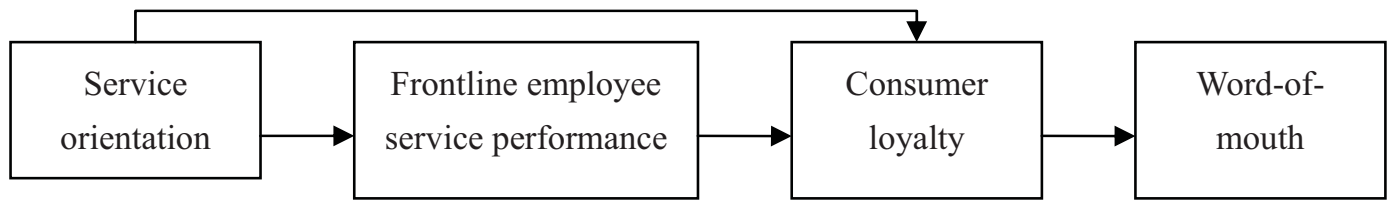

Figure 1. Research model 